\title{
IBM PEMBERDAYAAN KADER DALAM MENGELOLA TAMAN OBAT KELUARGA MELALUI KOMPOSTING
}

\author{
Eko Hartini ${ }^{1}$, Kismi Mubarokah $^{2}$, Eni Mahawati ${ }^{3}$ \\ ${ }^{1,2,3}$ Program Sarjana Kesehatan Masyarakat Universitas Dian Nuswantoro \\ E-mail: 1eko.hartini@dsn.dinus.ac.id, ${ }^{2}$ kismi.mubarokah@dsn.dinus.ac.id, \\ 3eni.mahawati@dsn.dinus.ac.id
}

\begin{abstract}
Abstrak
Pengelolaan Taman Obat Keluarga (TOGA) di Kelurahan Krobokan, dilakukan oleh masing-masing RW atau RT dan belum maksimal. Permasalahan yang terjadi pada saat musim kemarau panjang tanaman tampak kering, sedangkan saat musim penghujan tumbuh tanaman-tanaman gulma. Selama ini saat melakukan bersih-bersih sampahn dedaunam hanya ditimbun di tempat sampah, kemudian diangkut ke Tempat Sampah Sementara (TPS) atau malah terkadang dibakar. Kondisi ini dapat menyebabkan pencemaran udara. Tanaman yang ditanam juga belum memberikan hasil dengan baik, karena tidak dilakukan pemupukan dikarenakan mahalnya harga pupuk. Solusi yang ditawarkan adalah mengolah sampah daun dengan menggunakan tong "Komposter" modifikasi. Keunggulan dari tong ini adalah selain menghasilkan kompos, juga akan diperoleh produk lain berupa pupuk cair dan biogas. Kegiatan Pemberdayaan kader dalam mengelola TOGA diikuti oleh 26 orang. Pengetahuan kader tentang komposting dan TOGA adalah sangat baik, kader memiliki sikap yang positif dan mendukung. Kader dapat melakukan komposting menggunakan tong komposter ini dengan baik. Tindak lanjut dari kegiatan ini adalah diperlukan pendampingan sampai produk kompos matang dan diaplikasikan pada tanaman obat keluarga.
\end{abstract}

Kata Kunci: taman obat keluarga, komposter, kader

\section{PENDAHULUAN}

Taman Obat Keluarga (TOGA) merupakan konsep pemanfaatan pekarangan atau lahan guna budidaya tanaman yang berkhasiat sebagai obat. Kebiasaan ini sudah dilakukan sejak lama oleh para ibu rumah tangga sehingga kegiatan ini masuk dalam pogram kerja Pembinaan Kesejahteraan Keluarga (PKK). Berdasarkan data Riskesdas 2010, Propinsi Jawa Tengah merupakan salah satu propinsi dengan presentase penggunaan jamu tertinggi.

Hasil penelitian Diana Sari, dkk (2011), di Kabupaten Bogor program TOGA telah dikembangkan di beberapa desa, sedangkan di Kabupaten Karanganyar program ini disisipkan dalam program lain terkait dengan faktor ekonomi dan di Kabupaten Gianyar program TOGA berasal dari tanaman hias. Saat ini program TOGA dirasa berkurang gaungnya, hal ini disebabkan rendahnya pemanfaatan tanaman obat dan kurangnya sosialisasi pengembangan program TOGA di masyarakat oleh Puskesmas.

Implementasi program TOGA di perkotaan tergantung dari kebijakan di wilayah setempat, apakah program tersebut masuk salah satu program kerja atau tidak. Pelaksanaannya biasanya dilakukan di lingkup wilayah Rukun Warga (RW), dan pengelolaannya diserahkan pada masing-masing Rukun Tetangga (RT). Praktik pengelolaannya banyak kendala yang terjadi, hal ini disebabkan warga merasa kurang memiliki dan kurang mendapatkan manfaatnya. Akibat dari kondisi ini perawatan terhadap tanaman kurang, sehingga tanaman tidak dapat tumbuh dengan baik. Selain itu, juga disebabkan kurangnya pengetahuan warga, waktu dan dana untuk mengelola tanaman. 
Tanaman obat yang biasa ditanam antara lain, sirih, kunyit, temulawak, jahe, kumis kucing, daun binahong, daun beluntas, kencur, sambiloto dan temu ireng. Agar tanaman dapat tumbuh dengan baik diperlukan unsur hara NPK atau pupuk yang cukup. Dalam rangka mengurangi penggunaan pupuk kimia, dapat digunakan pupuk kompos.

Kompos merupakan pupuk organik buatan manusia yang dibuat dari proses pembusukan sisa-sisa buangan mahluk hidup (tanaman maupun hewan). Kompos tidak hanya menambah unsur hara, tetapi juga menjaga fungsi tanah sehingga tanaman dapat tumbuh dengan baik (Yuwono, D., 2005). Kompos memiliki banyak kelebihan dibandingkan pupuk kimia yang ada di pasaran, antara lain lebih murah, ramah lingkungan serta memiliki kemampuan untuk memperbaiki struktur kualitas tanah secara fisik, membuat $\mathrm{PH}$ tanah lebih stabil dan mendukung pertumbuhan tanaman dengan kualitas nutrisi tanah yang lebih baik sesuai dengan kebutuhan tanaman sehingga tanah dengan pupuk kompos menjadi media tumbuh yang lebih baik. Kompos juga menurunkan secara efektif kandungan bahan pencemar di tanah serta berbagai mikrobiologi yang merugikan. Selama ini kompos belum banyak dihasilkan dan didayagunakan oleh masyarakat antara lain karena belum efektifnya sosialisasi dan pendampingan ke masyarakat dibandingkan promosi pupuk kimia oleh berbagai produsen komersial yang dengan gencar dilakukan melalui berbagai media komunikasi. Hal tersebut sangat membutuhkan peran aktif tokoh masyarakat setempat didukung petugas/praktisi kesehatan.

Selama ini telah terbukti keberhasilan beberapa program kesehatan dengan keterlibatan kader, namun dalam bidang pelestarian lingkungan belum dikelola dengan baik sebagaimana bidang program kerja lainnya. Berdasarkan berbagai uraian tersebut di atas, maka perlu dilakukan pemberdayaan kader dalam mengelola TOGA guna mengoptimalkan upaya pelestarian lingkungan setempat dan meningkatkan potensi ekonomi masyarakat. Taman Obat Keluarga (TOGA) yang ada Kelurahan Krobokan, selama ini pengelolaannya dilakukan oleh masing-masing RW atau RT belum maksimal, sehingga saat musim kemarau tanaman tampak kering, bahkan beberapa ada yang tidak terdapat tanamannya. Permasalahan yang terjadi saat musim kemarau adalah, banyaknya sampah-sampah daun, sedangkan saat musim penghujan tumbuhnya tanaman-tanaman gulma. Selama ini saat melakukan bersih-bersih sampah dedaunan hanya ditimbun di tempat sampah kemudian diangkut ke Tempat Pembuangan Sampah Sementara (TPS) atau malah terkadang di bakar. Kondisi ini dapat menyebabkan terjadinya pencemaran udara.

Tanaman yang ditanam juga belum memberikan hasil dengan baik, karena tidak dilakukan pemupukan, dikarenakan mahalnya harga pupuk.

Sampah organik (dedaunan) secara alamiah dapat mengalami pembusukan, tetapi jika proses pembusukan/fermentasi tidak terkendali akan dapat menimbulkan bau yang tidak sedap (pencemaran udara), sehingga perlu dilakukan kontrol terhadap proses pembusukan tersebut, atau biasa disebut dengan komposting.

\section{TINJAUAN PUSTAKA}

Komposting adalah salah satu cara yang dianggap cukup efektif saat ini untuk menyelesaikan persoalan penumpukan sampah di Indonesia. Dengan menggunakan tabung dari bahan plastik limbah industri yang di desain sebagai alat pengolah khusus sampah organik (tabung komposter). Sampah organik yang mudah terurai/busuk akan menjadi kompos sebagai media tanam dan pupuk organik cair, dengan tanpa memotong, mencacah dan mengaduk sampah organik (Santoso, 2015). 


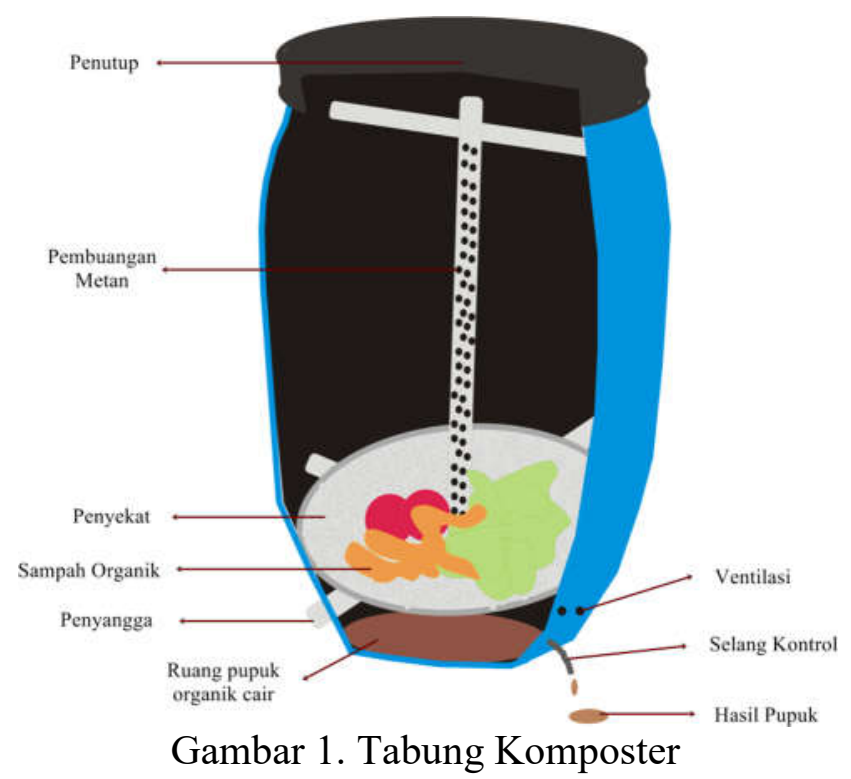

Tabung komposter ini terbuat dari plastik untuk menghindari proses pengkaratan dan memiliki daya tahan pakai yang kuat. Tempat sampah ini memiliki dua sisi yang dipisahkan oleh sekat di dalamnya yang berfungsi untuk memisahkan sampah padat dengan pupuk cair organik. Ketika cairan menetes ke ruang bawah, aroma sampah akan terbuang melalui lubang ventilasi secara bertahap yang ada di seputar sisi bawah.

Fermentasi sampah di dalam ruang tidak menimbulkan bau menyengat bila dibantu dengan bioaktivator untuk menguraikan sampah. Tempat sampah organik diisi sampah setiap hari. Batas jenuh sampah mencapai 10-12 bulan (kapasitas tempat sampah 120 liter). Setelah sampah mencapai tingkat jenuh (tidak menghasilkan cairan lindi), maka saat itu sisa sampah otomatis menjadi pupuk padat (kompos). Setelah didiamkan 3 minggu dalam keadaan tabung tertutup rapat, kemudian kompos dikeluarkan dan tabung siap digunakan kembali seperti proses awal.

\section{METODE PENELITIAN}

Kegiatan pengabdian masyarakat "Pemberdayaan Kader dalam Mengelola TOGA melalui Komposting" di Kelurahan Krobokan Semarang Barat.

Adapun tahapan pelaksanaan kegiatan adalah sebagai berikut:

a) Persiapan kegiatan, meliputi peijinan, pembuatan media penyuluhan dan tong komposter, koordinasi dengan kader.

b) Kegiatan pelatihan, meliputi pretest, penyuluhan dan praktik, penguatan.

c) Pendampingan kader, memantau penggunaan komposter.

\section{HASIL DAN PEMBAHASAN}

\section{A. Karakteristik Peserta Pemberdayaan}

Kegiatan pemberdayaan kader dalam mengelola TOGA melalui komposting di Kelurahan Krobokan Semarang Barat diikuti oleh 26 orang kader, dengan karakteristik sebagai berikut:

Tabel 1.

Karakteristik Peserta Pemberdayaan Kader dalam Mengelola TOGA melalui Komposting di Kelurahan Krobokan Semarang Barat Tahun 2017 


\begin{tabular}{ccl}
\hline No & Parameter & \multicolumn{1}{c}{ Analisa Deskriptif } \\
\hline 1 & Umur & Minimal 30 tahum \\
& & Maksimal 66 tahun \\
2 & Pendidikan & SD $=1$ orang $(3,8 \%)$ \\
& & SLTP $=3$ orang $(11,5 \%)$ \\
& & SLTA $=15$ orang $(57,7 \%)$ \\
& & Akademik $=1$ orang $(3,8 \%)$ \\
& & S1 $=6$ orang $(23,2 \%)$ \\
3 & Pekerjaan & Pegawai negeri $=5$ orang $(19,2 \%)$ \\
& & Pegawai swasta $=3$ orang $(11,5 \%)$ \\
& & Berdagang $=2$ orang $(7,8 \%)$ \\
& & Ibu rumah tangga $=16$ orang $(61,5 \%)$
\end{tabular}

Berdasarkan Tabel 1, diketahui peserta berada dalam usia produktif (30-60 tahun) dan pendidikan yang cukup baik (57,7\% SLTA), sehingga peserta memiliki kemampuan untuk menerima informasi dan mengikuti pelatihan yang diberikan.

\section{B. Pengetahuan Peserta tentang Komposting dan TOGA}

Tahap pertama dalam kegiatan ini adalah memberikan pelatihan tentang pembuatan kompos menggunakan tong "Komposter" yang mempunyai kemampuan dapat mengolah sampah organik menjadi kompos, pupuk cair dan gas. Peserta diberikan pre-test untuk mengetahui pemahaman dan kemampuan awal peserta dalam pembuatan kompos.

Tabel 2.

Hasil Pre Test Peserta Pemberdayaan Kader dalam Mengelola TOGA melalui Komposting di Kelurahan Krobokan Semarang Barat Tahun 2017

\begin{tabular}{clcc}
\hline \multirow{2}{*}{ No } & \multicolumn{1}{c}{ Pertanyaan } & \multicolumn{2}{c}{ Jawaban } \\
\cline { 3 - 4 } & & Benar & Salah \\
\hline 1 & Nama alat pengolah sampah menjadi kompos & $25(96 \%)$ & $1(4 \%)$ \\
2 & Jenis sampah yang dapat dibuat menjadi kompos & $25(96 \%)$ & $1(4 \%)$ \\
3 & Produk yang dihasilkan dari komposter & $9(35 \%)$ & $17(65 \%)$ \\
4 & Jenis sampah yang dapat diuraikan oleh mikroba & $23(89 \%)$ & $3(12 \%)$ \\
5 & Keunggulan Pengomposan & $16(62 \%)$ & $10(38 \%)$ \\
6 & Kepanjangan dari TOGA & $24(92 \%)$ & $2(8 \%)$ \\
7 & Contoh TOGA & $22(85 \%)$ & $4(15 \%)$ \\
\hline
\end{tabular}

Pengetahuan yang dimiliki oleh peserta tentang pengolahan kompos sudah sangat baik sekali, sehingga memudahkan penyaji dalam memberikan pelatihan. Terlihat pada Tabel 2 , sebanyak $96 \%$ peserta telah mengetahui nama alat pengolah sampah menjadi kompos, yaitu komposter. Peserta (96\%) dapat menyebutkan bahwa sisa sayuran, kulit buah dan daundaunan adalah contoh sampah yang dapat diolah menjadi kompos. Istilah sampah organik dapat dijawab dengan baik oleh peserta $(89 \%)$.

Keunggulan pengomposan yaitu teknologinya mudah, alat dan bahan mudah didapat serta biaya yang dibutuhkan murah dijawab dengan benar oleh $62 \%$ peserta. Sedangkan, pertanyaan tentang produk yang dihasilkan oleh komposter yang akan digunakan dalam pelatihan ini hanya $35 \%$ peserta yang dapat menjawab dengan benar. Hal ini karena, selama ini yang diketahui oleh peserta, produk yang dihasilkan oleh pengomposan hanyalah kompos. Padahal dengan adanya modofikasi pada tong "Komposter" selain dihasilkan kompos dapat pula dihasilkan pupuk cair dan biogas. 


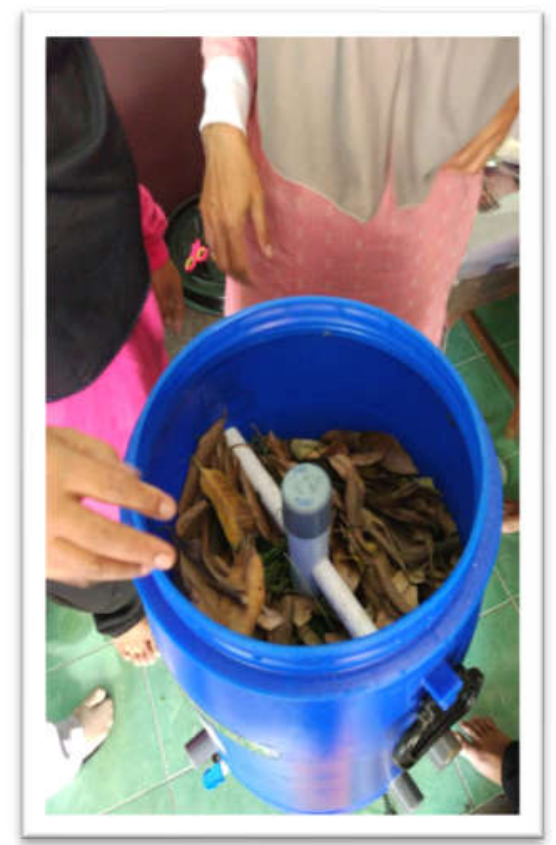

Gambar 2. Bagian Dalam Tabung Komposter

Tabung komposter pada Gambar 1. memiliki dua sisi yang dipisahkan oleh sekat di dalamnya yang berfungsi untuk memisahkan sampah padat dengan pupuk cair organik. Ketika cairan menetes ke ruang bawah, aroma sampah akan terbuang melalui lubang ventilasi secara bertahap yang ada di seputar sisi bawah. Pada saat pupuk cair organik tampak dalam selang, maka perlu dituangkan dan atau ditampung dalam wadah, untuk selanjutnya dapat digunakan sebagai pupuk pada tanaman (Santoso, H., 2015).

Fermentasi secara terus-menerus akan membuat terbentuknya gas metan, dengan dilengkapi rangkaian penangkap gas, tabung "Komposter" ini juga mampu menghasilkan biogas. Keunggulan tabung "Komposter" ini merupakan informasi baru bagi peserta.

Hasil dari tabung komposter ini diharapkan dapat diaplikasikan oleh peserta untuk TOGA. Kepanjangan dari TOGA (Tanaman Obat keluarGA) dapat dijawab dengan benar oleh $92 \%$ peserta, dan sebanyak $85 \%$ dapat menyebutkan contoh dari TOGA, diantaranya lengkuas dan jahe.

\section{Sikap Peserta tentang Komposting dan TOGA}

Tujuan utama dari kegiatan ini adalah peserta (kader) mampu dan berdaya dalam pengelolaan TOGA, oleh karena itu perlu diketahui bagaimana sikap yang telah dimiliki oleh kader dalam pengelolaan TOGA melalui komposting.

Tabel 3

Sikap Peserta Pemberdayaan Kader dalam Mengelola TOGA

melalui Komposting di Kelurahan Krobokan Semarang Barat Tahun 2017

\begin{tabular}{llccc}
\hline \multirow{2}{*}{ No } & Pernyataan & \multicolumn{3}{c}{ Sikap } \\
\cline { 3 - 5 } & Setuju & $\begin{array}{c}\text { Ragu- } \\
\text { Ragu }\end{array}$ & $\begin{array}{c}\text { Tidak } \\
\text { Setuju }\end{array}$ \\
\hline 1 & $\begin{array}{l}\text { Mengolah sampah adalah kegiatan yang } \\
\text { merepotkan }\end{array}$ & $9(35 \%)$ & & $17(65 \%)$
\end{tabular}


2 Membuat kompos menyenangkan

karena banyak manfaatnya

3 Pupuk kompos lebih aman bagi

tanaman daripada pupuk kimia

4 Menanam TOGA di halaman rumah

lebih bermafaat daripada tanaman hias
$26(100 \%)$

$26(100 \%)$

$24(92 \%) \quad 1(4 \%) \quad 1(4 \%)$

Pada Tabel 3 diketahui, 65\% peserta setuju bahwa mengolah sampah bukan kegiatan yang merepotkan, $100 \%$ peserta merasa senang membuat kompos karena banyak manfaatnya, karena kompos lebih aman daripada pupuk kimia. Peserta sebanyak 92\% setuju menanam tanaman obat keluarga lebih bermanfaat daripada tanaman hias. Kondisi ini merupakan modal yang sangat baik untuk program pemberdayaan, bahwa peserta memiliki sikap yang positif terhadap pengelolaan TOGA melalui komposting

Sikap positif yang dimiliki peserta (kader) di Kelurahan Krobokan Semarang Barat ditunjukkan dari praktik yang telah kader lakukan selama ini.

Tabel 4

Praktik Peserta Pemberdayaan Kader dalam Mengelola TOGA

melalui Komposting di Kelurahan Krobokan Semarang Barat Tahun 2017

\begin{tabular}{clcc}
\hline \multirow{2}{*}{ No } & \multicolumn{1}{c}{ Pertanyaan } & \multicolumn{2}{c}{ Jawaban } \\
\cline { 3 - 4 } & \multicolumn{1}{c}{ Ya } & Tidak \\
\hline 1 & Melakukan pemilahan sampah rumah tangga & $17(65 \%)$ & $9(35 \%)$ \\
2 & Mengolah sampah menjadi kompos & $17(65 \%)$ & $9(35 \%)$ \\
3 & Cara membuat kompos: & & \\
& a. Dengan kapur tohor =15 orang & & \\
& b. Dengan EM4 = 1 orang & & \\
& c. Dengan kapur tohor dan EM4 = 1 orang
\end{tabular}

Kader di Kelurahan Krobokan Semarang Barat telah melakukan pengolahan kompos dengan menggunakan kapur tohor. Proses pembuatan kompos yang dilakukan sangat mudah, yaitu dengan mengumpulkan sampah organik yang mudah membusuk, dimasukkan dalam wadah bekas ember cat ukuran 5 liter kemudian dicampur dengan kapur tohor. Kendala yang dialami oleh peserta adalah kompos yang dibuat lama matangnya. Hal ini terjadi, karena mikroba kurang dapat bekerja dengan baik, khususnya mikroba yang memanfaatkan bahan organik sebagai sumber energi. Pemberian air dan aerasi yang kurang juga dapat membuat kompos lama matangnya.

Proses penngomposan yang terjadi secara alami berlangsung dalam waktu cukup lama, sekitar 2-3 bulan bahkan ada yang 6-12 bulan tergantung bahannya. Oleh karena itu para ahli melakukan berbagai macam upaya untuk mempercepat proses tertentu. Proses tersebut dapat dipercepat menjadi 2-3 minggu tergantung pada bahan dasarnya, antara lain dengan menambahkan bioaktivator seperti EM4 (Indriani, 2010)

EM4 sebenarnya adalah singkatan untuk effective microorganism 4. EM4 merupakan larutan yang mengandung 80 jenis mikroorganisme yang dapat mempercepat pengomposan. Dengan menambahkan EM4, pengomposan dapat berlangsung secara anaerob dan bau dapat dikurangi. Kompos yang dihasilkan melalui pemberian EM4 sering disebut bokashi (Indriani, 2010)

\section{Membuat Kompos dengan Tong "Komposter"}


Kegiatan pelatihan diawali dengan pre-test, selanjutnya peserta diberi leaflet dan diminta untuk membaca media tersebut. Materi disampaikan oleh penyaji dengan menggunakan Power Point dengan sesekali diselingi interaksi dengan peserta.

Setelah cukup mendapatkan informasi tentang bagaimana cara menggunakan tong "Komposter", peserta diminta untuk praktik secara langsung. Peserta dibagi menjadi 2 kelompok, dengan bekal membawa kantong kresek besar peserta mencari sampah organik di sekitar tempat pelatihan. Selanjutnya, sampah dimasukkan ke dalam tong (keadaan sampah boleh utuh atau terpotong). Kemudian semprotkan larutan EM4. Selanjutnya, peserta diingatkan untuk setiap saat dapat menambahkan sampah organik ke dalam tong dan melakukan penyemprotan jika sampah sangat kering.

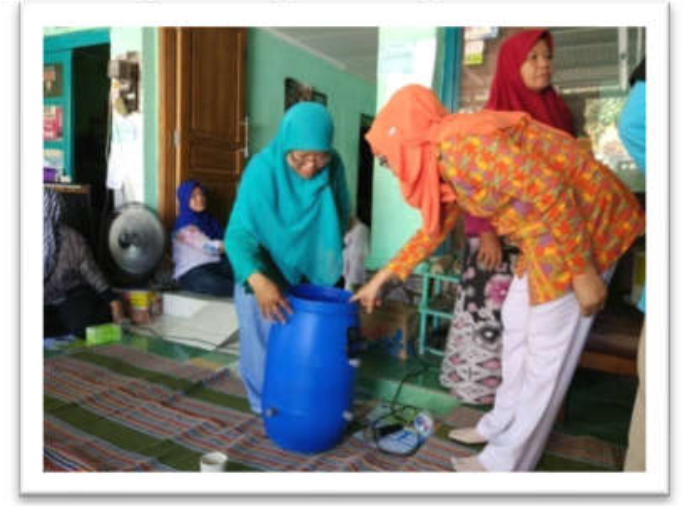

Gambar 3. Praktik Komposting

Satu bulan setelah kegiatan pelatihan, tim mengunjungi salah satu taman TOGA dimana tong "Komposter" berada, ternyata tong dimanfaatkan dengan baik, hanya saja tidak dilakukan penyemprotan EM4 dengan rutin sehingga kompos juga belum matang. Hal ini terjadi karena adanya kendala kesibukan masing-masing kader. Oleh karena itu, penguatan dan motivasi perlu untuk senantiasa dilakukan.

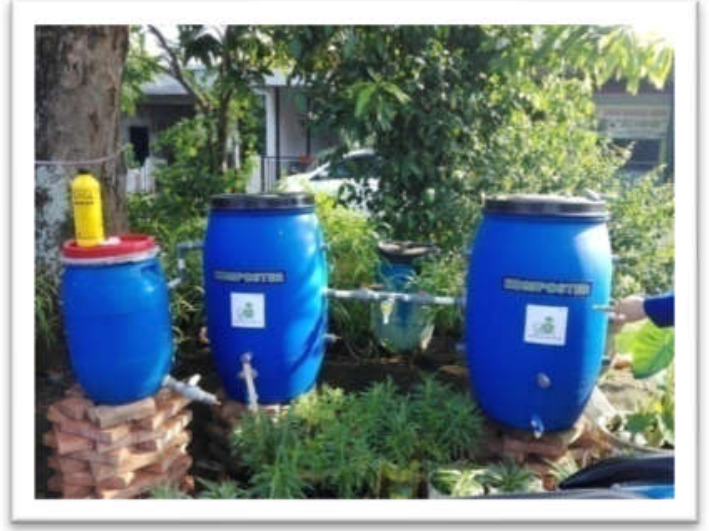

Gambar 4. Aplikasi Komposter di TOGA

\section{KESIMPULAN}

1. Pengetahuan kader tentang komposting dan TOGA sangat baik.

2. Sikap kader terhadap komposting dan TOGA adalah positif dan mendukung.

3. Peserta dapat melakukan komposting dengan menggunakan tong komposter dengan baik.

\section{SARAN}


1. Diperlukan pendampingan sampai kompos yang dihasilkan matang dan dapat diaplikasikan pada tanaman TOGA.

2. Pemberdayaan kader dalam mengelola TOGA perlu ditingkatkan dan dilakukan secara berkelanjutan.

\section{DAFTAR PUSTAKA}

Heru Santoso. 2015. Indonesia Bebas Sampah 2020. Jakarta: Penerbit Mandiri.

Ida Diana Sari, Yuyun Yuniar, Selma Siahaan, Riswati, Muhamad Syaripuddin. 2015. Tradisi Masyarakat dalam Penanaman dan Pemanfaatan Tumbuhan Obat Lekat di Pekarangan. Jurnal Kefarmasian Indonesia. 2015;5(2):123-132

Indriani Yovita Hety. 2010. Membuat Kompos Secara Kilat. Jakarta: Penebar Swadaya

Riset Kesehatan Dasar, 2010. Badan Litbangkes Kemenkes RI

Yuwono Dipo. 2005. Kompos. Jakarta: Penebar Swadaya. 